\section{Iceberg Ships}

For most of history, ice was found, not made. Sir Francis Bacon outlined the essential problem in 1631 in his treatise Sylva Sylvarum, "Heat we have in readiness in respect of the fire, but for cold we must stay till it cometh or seek it in deep caves or high mountains." As an early exception to this rule, the inventive ancient Egyptians were able to manufacture ice in small quantities by letting the night winds cool water set out in porous trays on a bed of straw. In the morning the thin layer of ice formed by evaporative cooling was skimmed from the surface. The Roman Emperor Nero, when he was not fiddling to accompany citywide conflagrations, frequently sent his slaves into the mountains to retrieve snow and ice to cool his wine. Wealthy gourmands from Italy and France enjoyed ice cream made from natural sources during the Renaissance. In the United States, ice was treated as a crop that was harvested annually and transported by sled, boat, and train to municipal ice depots or privately owned ice houses for use during the summers. For several winters in the 1880s, the citizens of Montreal, Quebec, and St. Paul, Minnesota built magnificent palaces using blocks of lake ice to enliven their winter revelries. When the warm winter of 1890 yielded the poorest ice crop on record, interest rapidly turned to mechanical means of manufacturing ice that had been demonstrated on a small scale in the previous century.

In 1755, William Cullen was the first to produce ice using purely mechanical methods. A cold stream of vapor produced by pumping air across the surface of an open container of ether (the refrigerant) caused ice to form in a pan of water. Later, Nairne and Leslie experimented with sulfuric acid as a refrigerant, while Carre used ammonia, which would become the dominant technology.

The benefits to the public health achieved through the ready availability of ice as a food preserver cannot be underestimated. It allowed fruits and vegetables to be transported long distances without spoiling, and preserved eggs, milk, and meat for consuming at a later date. But ice could also be put to other uses. In the winter of 1943, it was investigated as an instrument of war.

In October of 1942, Geoffrey Pyke, a scientific advisor to Lord Louis Mountbatten (then Chief of Combined Operations for Great Britain) conceived the idea of constructing ships of ice as a means to dominate the seas and to take the air power of the Allies closer to the fields of battle. In a 35,000-word memo to Mountbatten outlining his ideas, Pyke spoke of a fleet of hundreds of unsinkable floating airfields of ice that could be made cheaply out of readily available seawater. These "bergships," as he called them, could dominate the shipping lanes and provide launching sites for air raids in the Mid Atlantic. Given sufficient wall thickness, the bergships would be impervious to the bombs and torpedoes of the enemy. Internal cooling systems and insulation could keep them from melting, and small engines could propel them to their strategic destinations. Best of all, Mother Nature's northern winters could be used to provide the energy necessary for the cooling process.

\section{Geoffrey Pyke conceived the idea of constructing ships of ice as a means to dominate the seas.}

After receiving assurances of the feasibility of the project from other science advisors, Winston Churchill was soon an avid supporter. A secret project dubbed "Habbakuk" was launched, with a goal of producing three working aircraft carrier bergships by the summer of 1944. The project name resulted from Pyke's misspelling of the Book of Habakkuk in the bible, where he found an inspirational theme for the endeavor, "...for I will work a work in your days, which you will not believe, though it be told you."

Due to its long, cold winters, most of the development work took place in Canada under the auspices of the National Research Council and various universities. Studies on bonding of ice to wood and steel were carried out at the University of Manitoba; methods of making ice (including flooding and cooling of water layers $1 / 16$ th thick, and the merits of using mixtures of snow or crushed ice in water) were the province of the University of Saskatchewan. At Lake Louise in Banff National Park, large blocks of lake ice were "welded" together into a beam $40 \mathrm{ft}$. long using slush as the bonding agent. The study of crack patterns and ejected debris from dynamite exploded under the ice cover of Lake Louise yielded essential information on the potential resistance of bergships to torpedo attacks. In laboratories across Canada and Great Britain, numerous samples of ice were subjected to compression, tension, and bending to determine the mechanical properties of the material.
But the early work was not encouraging: Natural ice proved to have an unacceptably low average modulus of rupture in bending of only $22.5 \mathrm{~kg} / \mathrm{cm}^{2}(2.2 \mathrm{MPa})$. Some samples failed by brittle fracture at loads as low as $4.9 \mathrm{~kg} / \mathrm{cm}^{2}(0.5 \mathrm{MPa})$. Fortunately, investigations of composite materials formed by the addition of small-scale reinforcing components (such as hay, cotton, flax, and wood fibers) were also being performed. In February of 1943 researchers Mark and Hohenstein at Brooklyn Polytechnic found that a $4 \%$ mixture of wood pulp in water yielded a frozen material with an average modulus of rupture of $50.0 \mathrm{~kg} / \mathrm{cm}^{2}(4.9 \mathrm{MPa})$, largely due to the crack-bridging properties of the pulp. Because it had some of the consistency and properties of concrete, they named the new composite "pykrete" in honor of Geoffrey Pyke. Pykrete was a tough material that could be worked on a lathe, and was soon the focus of the development effort.

Because time was of the essence, design of the bergships had to proceed concurrently with the materials research. Combining the takeoff and landing needs of modern military aircraft with the physical and mechanical properties of pykrete yielded an engineering specification. The runway would have to be $600 \mathrm{~m}$ long by $60 \mathrm{~m}$ wide for aircraft safety. The vessel needed to have a freeboard of $15 \mathrm{~m}$, and a wall thickness of $9 \mathrm{~m}$ to withstand heavy waves and possible torpedo damage without failure. Calculations showed that such a craft would weigh 2.2 million English tons (about 26 times that of the Queen Elizabeth) and have a draught of $45 \mathrm{~m}$. The pykrete would have to be insulated and maintained at $-15^{\circ} \mathrm{C}$ by forcing refrigerated compressed air through a network of ducts in the hull. In order to maintain its position in heavy wind and waves, a bergship would have to be equipped with 20 electric motors, each capable of producing 1100 B.H.P., to achieve a top speed of 7 knots. Steering would be done using a fin and rudder.

To test the feasibility of building such a craft, a scale model was constructed on Patricia Lake in Jasper National Park in the early months of 1943 (see Figure 1). This $60 \mathrm{ft}$. by $30 \mathrm{ft}$. ice block was $19.5 \mathrm{ft}$. high, with a wood frame construction. Galvanized iron pipes 6 in. in diameter were placed at 18-in. intervals throughout the walls of the block. The insulating material used was a mixture of asphalt with either charcoal or vermiculite, poured into the floors and walls to a thickness of $10 \mathrm{in.}$ and covered with a layer of insulating 


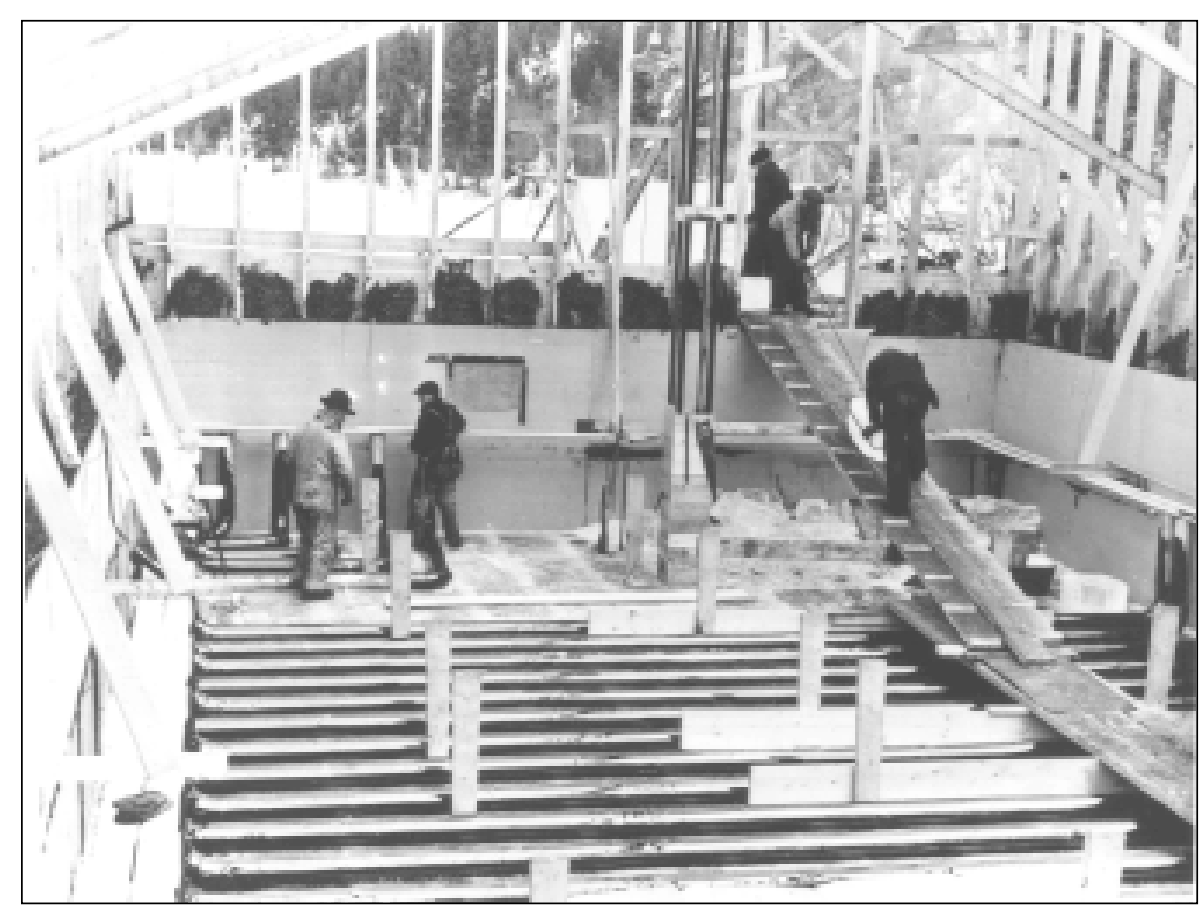

Figure 1. Wooden framework of the scale model iceberg ship, with cooling pipes in the floor. Workers on the right are moving ice blocks for placement in the base layer. Copyright 1992, the International Glaciological Society, National Research Council of Canada, and Lorne W. Gold. Reprinted with permission.

board. The completed structure was covered with a metal roof and monitored for internal temperature changes via thermocouples throughout the summer. While it was judged a success, the building of this experimental model pointed out many of the difficulties of construction that stood in the way of a working bergship. Leaking ducts, separation of charcoal and asphalt in the insulation, and an insufficient number of cold days to complete the project were just a few of the challenges.

In the end, the Habbakuk project was defeated by nature and the changing tides of war. Contradicting early hopes that Mother Nature would provide most of the energy for the extensive freezing process, it was realized that no place on earth could provide the necessary temperatures for the time required to make the project feasible. The alternative of building a refrigeration plant covering 100 acres to produce the 1.7 million tons of pykrete needed for one bergship was too outrageous to be considered. Also, the aircraft being produced in 1944 required a much longer landing strip than originally proposed, so the bergships being developed would be obsolete upon delivery. The project was abandoned by the British in January of 1944; the valiant Canadian effort was finally halted in December of 1945.

But the project was hardly a failure: For the first time, data was available on the fundamental mechanical properties of ice in its natural and manufactured forms. Later, geologists would use this data to form models for the creep behavior of glaciers, and materials scientists would revive ice composites such as pykrete in the attempt to design safer aircraft landing sites in the Arctic regions. Various proposals to deliver fresh water in the form of icebergs from Antarctica to drought-plagued areas such as California and Saudi Arabia have been entertained in recent decades. Each time, scientists have reviewed Habbakuk Project data to try to solve the same propulsion and insulation problems that Pyke and his colleagues faced. The fact that no one has succeeded yet points out the sheer magnitude of the challenge they took on optimistically in the 1940s.

TIM PALUCKA

For Further Reading: L.W. Gold, The Canadian Habbakuk Project: A Project of the National Research Council of Canada (International Glaciological Society, Cambridge, United Kingdom, 1993); M.F. Perutz, "A Description of the Iceberg Aircraft Carrier and the Bearing of the Mechanical Properties of Frozen Wood Pulp Upon Some Problems of Glacier Flow," Jour. of Glaciology 1 (3) p. 95; R.O. Cummings, The American Ice Harvests: A Historical Study in Technology, 1800-1918 (University of California Press, Berkeley and Los Angeles, 1949); and P.V. Hobbs, Ice Physics (Clarendon Press, Oxford, 1974).

\section{Access www.mrs.org/mic roworld/}

for information on the
MRS Materials Mic roWorld
project...

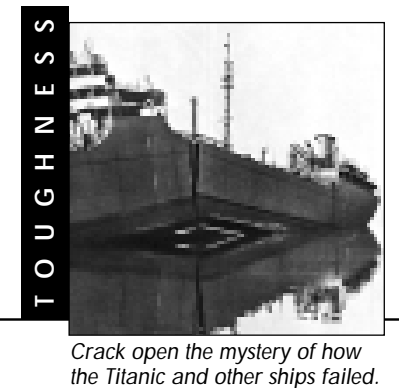

the Titanic and other ships failed.

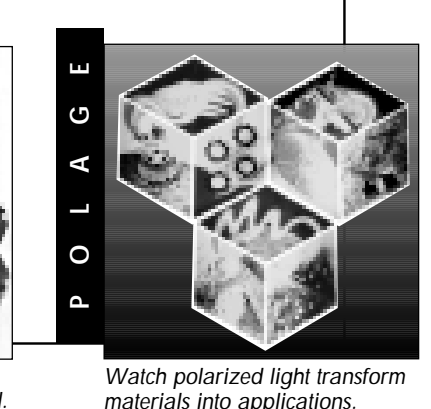

materials into applications. 